\title{
Patterns of computer and Internet usage among urology patients in two rural Northern Ontario communities
}

\author{
Erinma Abara, BA (Hons), ${ }^{*}$ Miya Narushima, PhD; ${ }^{\dagger}$ Emmanuel 0. Abara, MB, FRCSC, FACS, FICS ${ }^{\ddagger}$
}

\begin{abstract}
Introduction: We wanted to determine if the Internet can be used as a potential health promotion tool among urology patients in Northern Ontario. We identified patients' computer and Internet access and use patterns in Kirkland Lake and Kapuskasing, Ontario. Materials and Methods: This study was reviewed and approved by the ethics boards of the Kapuskasing and Kirkland Lake hospitals and Brock University. Data were collected by hand-written questionnaires in English and French. We performed a descriptive analysis of the data obtained.

Results: Out of the 137 questionnaires distributed and collected, we achieved a 95\% response rate (7 questionnaires were incomplete). There were 67 men (52\%) and 63 women (48\%) ranging in age from 24 to 84 (mean 56). Languages spoken were English $(57 \%)$, French (38\%) and other (5\%). We divided the responses into 3 groups: non-Internet users, those with a computer but no Internet access and Internet users. Internet and non-Internet users were studied. Our results indicated that younger respondents, those with higher education and higher paying jobs, used the computer and Internet more often. The main reason behind their Internet was to seek health information for themselves, family and friends. Conclusion: About half of the respondents (55\%) used the Internet to access health information. Patients' reactions toward online communication with their family physician were mixed. One limitation of this study is the small sample size, which inhibits making far-reaching conclusions. Our results demonstrate that individual empowerment, access to health information and access to services via emerging technologies are important issues for urology patients in rural Northern Ontario.
\end{abstract}

Can Urol Assoc J 2010;4(1):37-41

\section{Résumé}

Introduction : Nous avons cherché à déterminer si Internet peut être utilisé comme outil potentiel de promotion de la santé chez des patients en urologie dans le Nord de l'Ontario. Nous avons vérifié I'accès à un ordinateur et à Internet et les schémas d'utilisation de patients des régions de Kirkland Lake et de Kapuskasing (Ontario). Matériel et méthodologie : L'étude a été revue et approuvée par les comités d'éthique des hôpitaux de Kapuskasing et de Kirkland Lake et de la Brock University. Les données ont été recueillies à I'aide de questionnaires remplis à la main en anglais et en français. Nous avons ensuite procédé à une analyse descriptive des données.
Résultats : Sur les 137 questionnaires distribués et retournés, nous avons obtenu un taux de réponse de $95 \%$ (7 questionnaires n'ont pas été remplis). Les répondants comptaient 67 hommes (52\%) et 63 femmes (48\%) dont l'âge variait entre 24 et 84 ans (moyenne de 56 ans). Les langues parlées étaient l'anglais (57\%), le français (38\%) et d'autres langues (5\%). Nous avons divisé les réponses en trois groupes : ceux qui n'utilisent pas Internet, ceux qui ont accès à un ordinateur mais aucun accès à Internet et ceux qui utilisent Internet. Les patients utilisant ou n'utilisant pas Internet ont été étudiés. Nos résultats indiquent que les répondants plus jeunes, ayant un niveau de scolarité plus élevé et des emplois mieux rémunérés utilisent l'ordinateur et Internet plus souvent. La principale raison de l'emploi d'Internet était la recherche d'informations médicales pour eux-mêmes, pour leur famille et leurs amis.

Conclusion : Environ la moitié des répondants (55\%) utilisaient Internet pour trouver des renseignements sur la santé. Les réactions des patients vis-à-vis la communication en ligne avec leur médecin de famille étaient mitigées. Les résultats de l'étude sont limités par la petite taille de l'échantillon, ce qui empêche de tirer des conclusions profondes. Nos résultats montrent que la responsabilisation individuelle et l'accès à des renseignements et des services de nature médicale par le biais des nouvelles technologies sont des points importants pour les patients en urologie dans les régions rurales du Nord de I'Ontario.

\section{Introduction}

As a method of instant communication, the Internet has the potential to promote access to health information to geographically isolated regions and to marginalized groups (e.g., minorities, women and the elderly). Across several jurisdictions worldwide, health authorities are adopting Internet-related strategies to promote health in their populations. ${ }^{1}$ The expectations of these Internet-related strategies to reach citizens are high. The protection of patient privacy is a challenge.

Northern Ontario's large land mass, small population and dispersed communities make access to health care and information difficult. These realities direly affect the allocation of much-needed health care resources. It is not unusual for citizens to travel long distances to receive appropriate care. ${ }^{2,3}$ A viable strategy is needed to provide increased access to health care in Northern Ontario. The Internet may be a good tool in this direction. 
The purpose of this study is to determine whether the Internet can be used as a potential health promotion tool in Northern Ontario by identifying the patterns of computer and Internet use among urology patients in this community.

\section{Methods}

We used a bilingual hand-written questionnaire, which was distributed among patients seen over the course of 1 day at one of the monthly urologic clinics held by one of the authors (EOA) in Kapuskasing and Kirkland Lake. Participation was voluntary and informed consent was obtained.

The Research Ethics Board at Brock University, and the medical ethics boards at the Kirkland Lake and Kapuskasing hospitals reviewed and approved the questionnaires and the study design. The sealed questionnaires were distributed by the clinic administrative staff to prospective patientrespondents. The completed questionnaires and the consent forms were placed in 2 different sealed envelopes and returned to the primary investigator. The data were analyzed by Statistical Analysis Software (SAS). Three descriptive categories emerged from the data. Chi-square analysis was used to identify the relationships between demographic variables, computer use and patient perceptions of the Internet. The conceptual matrix (qualitative analysis) identified the perceptions of Internet users and their e-mail communication with their family physicians.

\section{Results}

The following questions guided the study:

1. Who uses the Internet in Northern Ontario, more specifically in Kirkland Lake and Kapuskasing?

2. Who uses the Internet for health-related purposes in Northern Ontario?

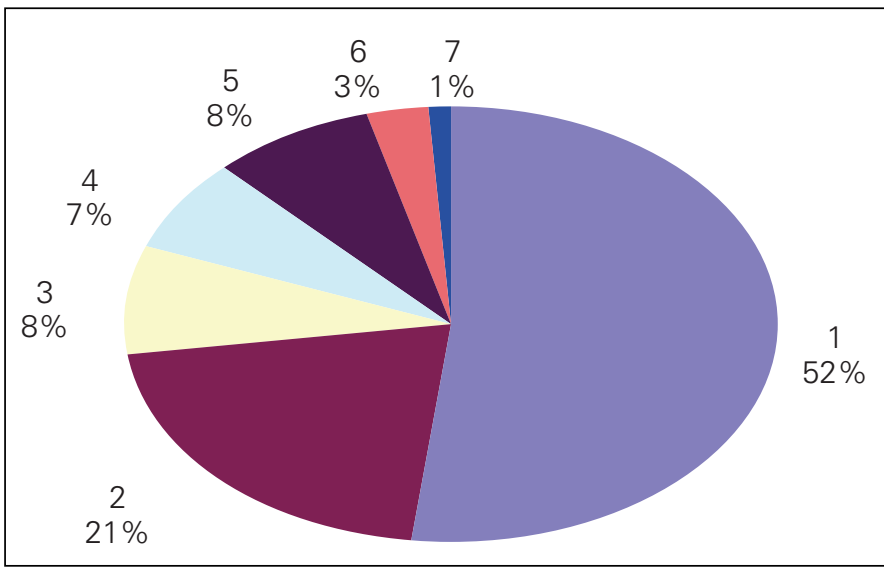

Fig. 1. Health information Internet-users seek. 1 = disease information; 2 = surgical information; 3 = alternative/complementary medicine; $4=$ diagnostic imaging procedure information; $5=$ area health facilities; $6=$ area physicians; $7=$ travel health information .
3. Are Internet users willing to communicate with medical practitioners through e-mail?

4. What types of health information are sought by Internet users?

5. Do age, education and economic status affect Internet usage in Northern Ontario?

6. Does language affect Internet usage in Northern Ontario? Three groups emerged from our results: (1) individuals with a computer and Internet access (Internet users); (2) individuals with a computer but no Internet access; and (3) individuals without a computer or Internet access (nonInternet users).

Our results show that Internet users were younger (average age 49) and had achieved higher education and better paying jobs. Most of them spoke English and 58\% were women, compared with $42 \%$ men (Table 1 ). Most respondents $(68 \%, 48 / 71)$ reported that they access the Internet 10 times or more per week.

Most respondents searched the Internet for disease information (Fig. 1). In rating the quality of health information online, 56\% (40/71) of respondents reported that the Internet was "somewhat useful" in providing good health information, $31 \%(22 / 71)$ said that the Internet was "useful" in providing good health information, and 13\% (9/71) reported that the Internet was "extremely useful." Internet users sought health information for themselves, friends and family or a specific problem (Fig. 2).

A part of the questionnaire addressed online communication with their family doctor. Only $23(32 \%)$ of the 71 Internet users answered this question. The answers were varied (Table 2). One out of the 23 respondents had a negative perception of e-mail communication with their family doctor.

Of the 59 non-Internet users, there were 9 people with computers but no Internet access, 6 used the computer for word processing and 3 to play computer games. When asked for the reason they did not have the Internet, 6 of them

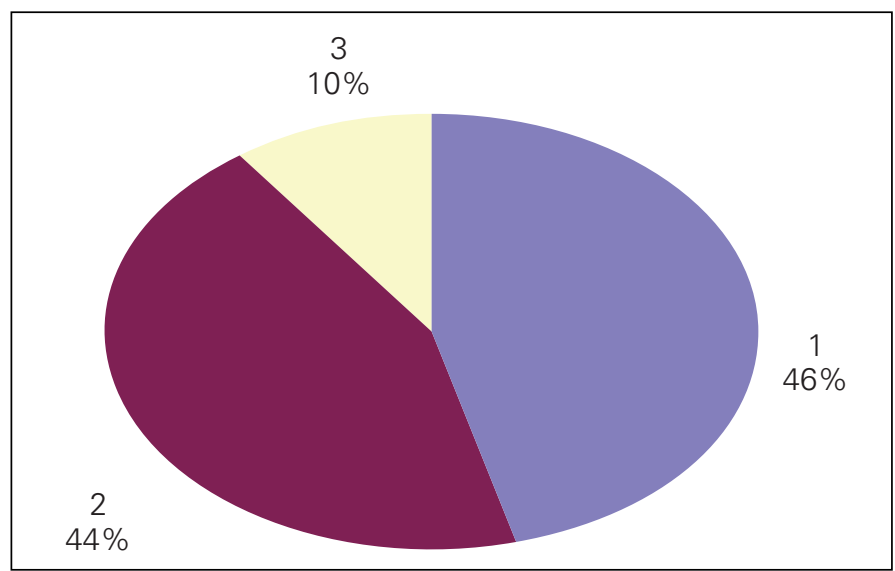

Fig. 2. Person/object of interest for whom Internet-users seek health information. 1 = for myself; 2 = for friends and family; 3 = for a specific problem. 
Table 1. Demographics of Internet users and non-Internet users

Internet Non-Internet

users, $\mathbf{n}=\mathbf{7 1}$ users, $\mathbf{n}=\mathbf{5 9}$

\begin{tabular}{lcc}
\hline Age distribution, yrs** & \\
$\leq 40$ & 16 & 2 \\
$41-60$ & 45 & 15 \\
$\geq 61$ & 10 & 42 \\
\hline Sex distribution & & \\
$\quad$ Male & 27 & 38 \\
Female & 44 & 21 \\
\hline Language & & \\
English & 36 & 24 \\
French & 27 & 31 \\
Others & 0 & 4 \\
Bilingual (English and French) & 8 & 0 \\
\hline Educational status ${ }^{*}$ & & \\
Elementary school & 3 & 25 \\
High school & 43 & 27 \\
College/university & 25 & 7 \\
\hline Income status* & & \\
\$10 000-\$20 000 & 14 & 19 \\
\$21 000-\$40 000 & 30 & 8 \\
$>$ \$41 000 & 18 & 6 \\
Unemployed & 9 & 6 \\
Retired & 0 & \\
\hline$*$ statistically significant (<0.0005);** statistically significant $(<0.0001)$. & \\
\hline
\end{tabular}

stated they did "not need the Internet" or "did not know anything about Internet" or "could not afford it." When asked about the Internet as a potential source of health promotion, 7 of the 9 respondents did not consider the Internet to be useful, yet they would prefer to access health information in their language in another format.

There were 59 non-Internet users; the mean age was 65.5 and most of the respondents in this group were less educated men who spoke languages other than English (Table 1). When asked for the reason they did not have the Internet, they stated "they didn't know anything about the Internet" and cited their inability to afford it. Participants were also asked whether they would like to learn about Internet and most of them were not interested. However, most of these respondents (37/59 or $63 \%$ ) said they would be interested in receiving health promotion information in a different format, in their language.

\section{Discussion}

There are many websites that provide medical and health information. People surf the web daily for health related matters. ${ }^{4,5}$ Internet access to health information is instant, convenient and attractive for patients and their health-care providers. Several studies among urology patients found that those who used the Internet assumed an active role in their own care. ${ }^{6-9}$ Pautler and colleagues found that among a group of prostate cancer patients in a tertiary centre, information gleaned from the Internet influenced their choice of treatment. ${ }^{6}$ In another study, prostate cancer patients preferred the Internet and video learning aids for sexual information before and after their prostatectomy or brachytherapy. ${ }^{8,10}$ Most of the studies of urology patients have been from tertiary health facilities or academic centres. In this study, we included patients from rural Ontario. We were impressed to find that over half of the respondents (55\%) used the Internet. It is possible that increased Internet use may be a trend in communities in rural Northern Ontario. We were concerned about bias, due to the select group of patients and the small sample size. Nonetheless, our findings support the notion that the Internet, when used as a health promotion tool, can be useful in these isolated communities.

Our finding that non-Internet users were older is in line with the published literature. ${ }^{4,6}$ Fox, in the Pew Internet and American Life Project, found that $22 \%$ of Americans, 65 and older used the Internet compared to $2 \%$ in 1996 and $15 \%$ in 2000 . Fox's results also show that among older Americans there has been an increase in Internet activities in health searches, e-shopping and online banking. Although we did not assess the trend of Internet usage, the existing literature suggests that people with Internet access tend to live with it and expand its usage. Health-care providers including urologists should keep the changing demographics of the present senior generation in mind in their current and future care planning.

Gender-related Internet and computer usage patterns have fluctuated over the years. ${ }^{5}$ Initially, older males were more likely to use the Internet, compared to older females. In our study, most of the Internet users were females. This

Table 2. Conceptual matrix of patient attitudes toward email communication with their family physician

\begin{tabular}{ll}
$\begin{array}{l}\text { Don't know if medical } \\
\text { practitioner has e-mail }(n=12)\end{array}$ & "Don't know if he has one." \\
\hline Didn't think of it $(n=4)$ & $\begin{array}{l}\text { "I never thought of } \\
\text { corresponding with him. } \\
\text { Doctors are so busy." }\end{array}$ \\
\hline No family doctor $(n=2)$ & "Do not have a family doctor." \\
\hline Not necessary $(n=4)$ & $\begin{array}{l}\text { "No need to." "I book an } \\
\text { appointment instead." }\end{array}$ \\
\hline $\begin{array}{l}\text { Medical practitioner } \\
\text { communication }(n=1)\end{array}$ & $\begin{array}{l}\text { "He doesn't communicate well } \\
\text { when I'm there in person. I } \\
\text { don't believe he would do well } \\
\text { through the Internet." }\end{array}$
\end{tabular}


result appears to be in line with current literature. This finding underscores the role of women in the society and states the importance of individual empowerment through media, such as the Internet, in self-care and health maintenance.

The relationship between income, education and age, as the Pew Project ${ }^{4}$ suggests, is significant. Our results show that, in Northern Ontario communities, Internet users are younger, have attained high levels of education and have more disposable income, compared to non-Internet users. Some of the respondents questioned the quality and validity of health information on the Internet. Several authors have addressed this. ${ }^{9,11-15}$ Morris and colleagues suggested that patient decision aids would be improved by the use of standardized labelling, provision of specific website addresses and access to an independent patient decision aid clearing house. ${ }^{11}$ Atack and colleagues reported on patient satisfaction with tailored online education and the website Patient Education Prescription Project (PEP-Talk) website. ${ }^{12}$ By establishing the validity and currency of information and by ensuring privacy, it is believed that there will be more health promotion and information programs on the Internet.

In our study, more than $60 \%$ of Internet users stated that English was their primary language. Non-Internet users were more likely to speak other languages. These results may suggest an Internet literacy gap in rural Northern Ontario; these results may also be skewed due to the sample size.

Other authors have studied the usability of health websites among the elderly; ${ }^{15}$ others have assessed the accessibility, quality and reliability in English and Spanish websites. ${ }^{16}$ Future studies will examine ways to make the Internet more attractive and accessible to all. A study to assess the relevance of electronic-health (e-health) in their practice among urologists in rural areas could be performed.

From our study, it would appear that the rural population of Northern Ontario, especially those younger than 60 , are embracing the Internet and are using it to seek out information about their health and other issues. Physicians, including urologists, in these rural areas should equip themselves with the knowledge, skills and tools to meet the demands of patients. Delivery of health care and information through agencies, such as the Ontario Telemedicine Network, ${ }^{17}$ is currently available and can help urologists in remote communities. Physicians, including urologists, who are knowledgeable about e-health will be wellpositioned to guide their patients to relevant websites. ${ }^{16,18,19}$

There are limitations to our study. Our patient population is small, with a patient base from a single urologist. However, unlike other studies reviewed in this discussion, our patient population had varied and multiple diagnoses.

\section{Conclusion}

Among the respondents from rural Northern Ontario urology clinics, young educated English females use the computer and the Internet more often. Older, non-English speaking patients without a computer and/or Internet access want to have more health information in their own language and in a different format, other than the Internet. Patients' opinions regarding online communication with their family physician were mixed. There was anxiety about the protection of their privacy. Overall, our results show that patients would like to receive health information through the Internet and other formats.

The sample size limits any far-reaching conclusions. Future studies will include a cohort of patients from rural and urban areas in southern and northern Ontario, and perhaps a tertiary health facility/community to determine the impact and role of the Internet in health care. With the Ontario Telemedicine Network wired to the remotest areas in Northern Ontario, the time has come for the rural urologist to use technology, especially as related to e-health. ${ }^{17-19}$

From the *University of Windsor, Faculty of Law, Canterbury College-Whitgift; ${ }^{\dagger}$ Assistant Professor, Brock University, Faculty of Applied Health Sciences, St. Catharines, ON; FRichmond Hill Urology Practice and Prostate Institute, Richmond Hill, ON

Competing interests: None declared.

This paper has been peer-reviewed.

\section{References}

1. Eng T, Maxfield A, Patrick K, et al. Access to Health Information and Support. JAMA 1998;280;1371-5.

2. Tepper JD, Schultz SE, Rothwell DM, et al. Physician Services in Rural and Northern Ontario. Toronto: Institute for Clinical Evaluative Sciences; 2005.

3. Southcott C. The Changing Population of Northern Ontario 2001 to 2006. Lakehead University for the Local Board Areas in Northern Ontario; 2006.

4. Fox S. Older Americans and the Internet. Washington, DC: Pew Internet and American Life Project. 2004. http://www.pewinternet.org/Reports/2004/Older-Americans-and-the-Internet.aspx. Accessed December 8, 2009.

5. Stark-Wroblewski K, Edelbaum J, Ryan J. Senior Citizens who use E-mail. Educ Gerontol 2007;33: 293-307.

6. Pautler SE, Tan JK, Dugas GR, et al. Use of the Internet for Self-education by patients with prostate cancer. Urology 2001;57:230-3.

7. McFarlane N, Parker JH, Denstedt JD. Urology and the Internet. Contemp Urol 1999;11:38-52.

8. Davison BJ, Keyes $M$, Elliott $S$, et al. Preferences for sexual information resources in patients treated for early stage prostate cancer with either radical prostatectomy or brachytherapy. BJU Int 2004;93:965-9.

9. Ziebland S, Chapple A, Dumelow C, et al. How the Internet affects patient's experience of cancer: a qualitative study. BMJ 2004;328:564

10. Davison BJ, Gleave ME, Goldenberg SL, et al. Assessing information and decision preferences of men with prostate cancer and their partners. Cancer Nurs 2002;25:42-9.

11. Morris D, Drake E, Saarimaki A, et al. Can people find patient decision aids on the Internet? Patient Educ Couns 2008;73:557-60. 
12. Atack L, Luke R, Chien E. Evaluation of Patient Satisfaction with Tailored Online Patient Education information. Comput Inform Nurs 2008;26:258-64.

13. Gustafson DH, Hawkins $R$, Boberg $E$, et.al. Impact of a patient centred computer based health information/support system. Am J Prev Med 1999;16:1-9.

14. Nahm ES, Preece J, Resnick B, et al. Usability of Health Websites for older adults: a preliminary study. Computer Nursing 2004;92:326-34.

15. Berland GK, Elliott MN, Morales LS, et al. Broader MS. Health Information on the Internet: Accessibility, quality and readability in English and Spanish. JAMA 2001;285:2612-21.

16. Glasgow RE, Boles SM, McKay HG, et al. The D-Net Diabetes Self-Management Program: long term implementation, outcomes and generalization results. Prev Med 2003;36:410-9.
17. Ontario Telemedicine Newtork. Online: httrp://www.otn.ca/en/otn/who-we-are/. Accessed December $21,2009$.

18. Anderson JG, Rainey MR, Eysenbach. The Impact of Cyber Healthcare on the Physician-Patient Relationship. $J$ Med Syst 2003;27:68-84.

19. Eysenbach $\mathrm{G}$, Kohler $\mathrm{CH}$. What is the prevalence of health-related searches on the World Wide Web? Qualitative and Quantitative analysis of search engine queries on the Internet. AMIA Annu Symp Proc 2003:225-9.

Correspondence: Erinma Abara, University of Windsor, Faculty of Law, Canterbury College-Whitgift, 2500 University Ave. West, Windsor, ON N9B 3Y1; Abara@uwindsor.ca

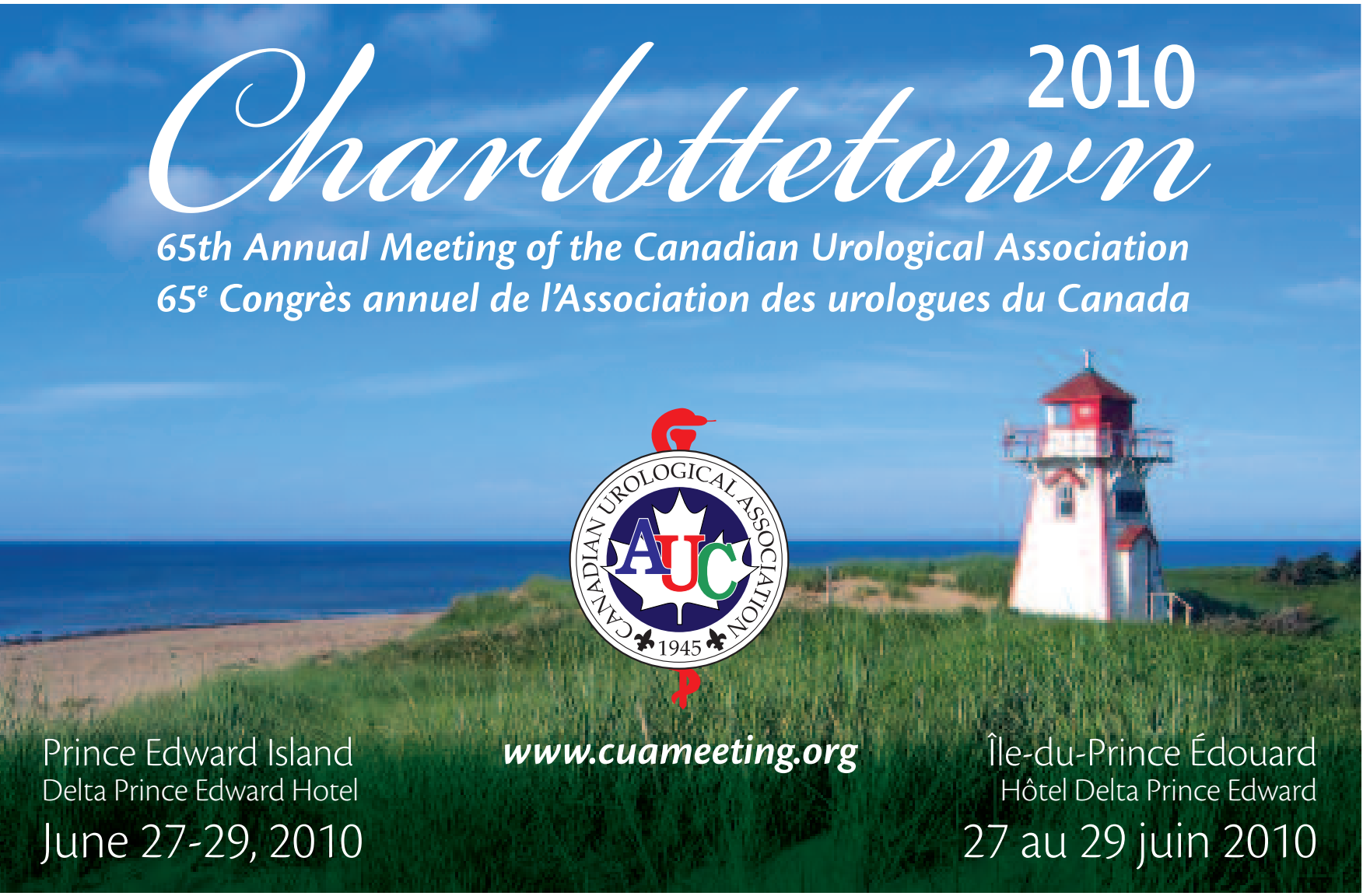

